\title{
MEDIA MASSA ISLAM DALAM TATANGAN GLOBAL (Analisis Dakwah dan Cyber Media di Indonesia)
}

\author{
Mokhamad Abdul Aziz \\ Program Magister Komunikasi dan Penyiaran Islam UIN Walisongo \\ Mokhamadabdulaziz@gmail.com
}

\begin{abstract}
$G$ lobalization requires people to be wise. Because, globalization has two different sides, can even contradict each other. On the one hand, globalization offers convenience and promises progress. However, on the other hand, globalization can be destructive, even destructive if one rejects it. Admittedly or not, the impact of globalization is very influential on the behavior and culture of people in developing countries, especially Indonesia. World globals and challenges must be addressed with wisdom and positive thinking, because globalization and modernization are indispensable and beneficial for progress.
\end{abstract}

Keyword: islamic mass media, Globalisasi, Cyber Media Indonesia

\begin{abstract}
ABSTRAK
$\mathrm{G}$ lobalisasi menuntut manusia bersikap bijak. Sebab, globalisasi memiliki dua sisi yang berbeda, bahkan bisa saling bertentangan. Di satu sisi, globalisasi menawaran kemudahan dan menjanjikan kemajuan. Namun, pada sisi yang lain, globalisasi bisa merusak, bahkan bisa menghancurkan jika salah menyikapinya. Diakui atau tidak, dampak globalisasi kenyataannya sangat berpengaruh terhadap prilaku dan budaya masyarakat di negara berkembang, khususnya Indonesia. Pengglobalan dunia dan tantangannya harus disikapi dengan arif dan positive thinking, karena globalisasi dan modernisasi sangat diperlukan dan bermanfaat bagi kemajuan.
\end{abstract}

Kata kunci: Islamic Mass Media, Globalisasi, Cyber media Indonesia

$200 \mid \begin{aligned} & \text { Islamic Comunication journal } \\ & \text { Volume 02, Nomor 02, Juli-Desember } 2017\end{aligned}$ 


\section{PENDAHULUAN}

Globalisasi menuntut manusia bersikap bijak. Sebab, globalisasi memiliki dua sisi yang berbeda, bahkan bisa saling bertentangan. Di satu sisi, globalisasi menawaran kemudahan dan menjanjikan kemajuan. Namun, pada sisi yang lain, globalisasi bisa merusak, bahkan bisa menghancurkan jika salah menyikapinya. Diakui atau tidak, dampak globalisasi kenyataannya sangat berpengaruh terhadap prilaku dan budaya masyarakat di negara berkembang, khususnya Indonesia. Pengglobalan dunia dan tantangannya harus disikapi dengan arif dan positive thinking, karena globalisasi dan modernisasi sangat diperlukan dan bermanfaat bagi kemajuan.

Namun, masyarakat tidak boleh lengah dan terlena, karena era keterbukaan dan kebebasan itu juga menimbulkan pengaruh negatif yang akan merusak budaya bangsa. Menolak globalisasi bukanlah pilihan tepat, karena itu berarti menghambat kemajuan ilmu pengetahuan dan teknologi. Akan tetapi perlu kecerdasan dalam menyaring efek globalisasi. Akses kemajuan teknologi, informatka, dan komunikasi dapat dimanfaatkan sebagai pelestari dan pengembang nilai-nilai budaya lokal. Jati diri daerah harus terus tertanam di jiwa masyarakat Indonesia, serta harus terus, meningkatkan nilai-nilai keagamaaan. Dalam hal ini, media sangat berperan besar dalam proses sosialisasi kepada masyarakat.

Media massa begitu mempengaruhi masyarakat modern. Media bahkan telah menjadi kebutuhan primer bagi sebagian masyarakat di Indonesia. Di Era globalisasi ini, media mendekatkan jarak yang sebelumnya dianggap jauh daan sulit berkomunikasi atau sekadar tahu tentang keadaan belahan dunia lain. Sekarang, media menjadikan dunia seolah-olah tanpa jarak. Media massa adalah sebuah kekuatan yang sangat menentukan apa yang diketahui dan apa yang tidak diketahui masyarakat. Kepercayaan akan kekuatan itulah yang menyebabkan para pengiklan di seluruh dunia mengalirkan uang berlimpah kepada media untuk memasarkan produk mereka. Tapi kepercayaan akan kekuatan itu pula yang menyebabkan banyak pemerintah otoriter di dunia berusaha mengendalikan dunia.

Agner Fog (2004: 2) dalam artikelnya bertajuk "The Supposed and the Real role of Mass Media in Modern Democracy" menyatakan, media dilahirkan (lahir) sebagai penyangga demokrasi. Ia menjadi penyangga penting demokrasi, sebab media menyajikan informasi hiruk-pikuk bernegara, namun di lain pihak, media moderen pula turut serta menyumbangkan sejumlah solusi atas 
berbagai problemantika bangsa itu. dimanfaatkan untuk menyampaikan pesaanPernyataan Fog itu seolah mengingatkan kita kembali pada terminologi yang dibangun oleh Fred S Siebert (1963) yang menyatakan pers sebagai pilar keempat demokrasi, selain eksekutif, legislatif dan yudikatif. Siebert dalam bukunya Four Theories of the Press yang dipublikasikan tahun 1963 itu mengisyaratkan pentingnya keikutsertaan pers dalam melakukan kontrol atas tiga pilar kekuasaan tersebut.

Dalam alam demokrasi Indonesia yang mengenal banyak agama, tentu ini akan berdampak kepada ideologi dan ajaran yang mana yang akan mendominasi media massa. Karena agama yang dianut mayoritas masyarakat Indonesia adalah Islam, sudah menjadi hal yang wajar jika konten-konten keagamaan lebih didominasi ajaran Islam. Namun, selain karena factor pengguna media itu sendiri, pemilik media tentu juga memiliki misi tersendiri yang bisa saja berkaitan dengan banyak hal. Karena isi media bisa sangat beragam. Ada yang terang-terangan menggunakan identitas agama secara langsung, ada juga yang secara tersirat menyebarkan pesan-pesan religius tanpa mengidentifikasi diri sebagai "penganut" agama tertentu, terutma Islam. Dalam konteks dan perspektif itulah, artikel ini ditulis guna menyingkap bagaimana media memiliki peluang yang khas agar pesan dakwah. Semoga bermanfaat.

\section{MEDIA MASSA DAN PERANANYA}

Media massa adalah suatu istilah yang mulai dipergunakan pada tahun 1920-an untuk mengistilahkan jenis-jenis media yang secara khusus didesain untuk mencapai masyarakat yang luas. Pengertian Media Massa adalah berasal dari istilah bahasa inggris. Media massa merupakan Singkatan dari mass media of communication atau media of mass communication. Media massa adalah "komunikasi dengan menggunakan sarana atau peralatan yang dapat menjangkau massa sebanyak-banyaknya dan area yang seluas- luasnya. Komunikasi massa tak akan lepas dari massa, karena dalam komunikasi massa, penyampaian pesannya adalah melalui media. McQuail (2005: 3) menyatakan bahwa media massa merupakan sumber kekuatan alat kontrol, manajemen, dan inovasi dalam masyarakat yang dapat didayagunakan sebagai pengganti kekuatan atau sumber daya lainnya.

Selanjutnya, media massa memiliki beberapa karakteristik sebagaimana diungkapkan oleh Cangara sebagai berikut (Cangara, 2003: 134):

1. Bersifat melembaga: pihak yang mengelola media terdiri atas banyak orang, yakni mulai dari pengumpulan, 
pengelolaan, sampai pada penyajian informasi.

2. Bersifat satu arah: komunikasi yang dilakukan kurang memungkinkan terjadinya dialog antara pengirim dengan penerima. Kalau misalnya terjadi reaksi atau umpan balik maka biasanya memerlukan waktu dan tertunda.

3. Meluas dan serempak: dapat mengatasi rintangan waktu dan jarak karena memiliki kecepatan. Bergerak secara luas dan simultan, di mana informasi yang disampaikan diterima oleh banyak orang pada saat yang sama.

4. Memakai peralatan teknis atau mekanis: seperti radio, televisi, surat kabar, dan semacamnya.

5. Bersifat terbuka: pesan dapat diterima oleh siapa saja dan di mana saja tanpa mengenal usia, jenis kelamin, agama, dan suku bangsa. Beberapa bentuk media massa meliputi alat-alat komunikasi mekanis seperti surat kabar, film,radio, dan televisi.

Sedangkan menurut McQuail (1994: 70), media massa memiliki beberapa fungsi, yaitu:

1. Informasi: Menyediakan informasi tentang peristiwa dan kondisi dalam masyarakat dan dunia Menunjukkan, hubungan kekuasaan, Memudahkan inovasi adaptasi dan kemajuan.

2. Korelasi: Menjelaskan, menafsirkan, mengomentari makna peristiwa dan informasi, menunjang otoritas dan norma-norma yang mapan, melakukan sosialisasi, mengkoordinasikan ngbeberapa kegiatan, membentuk kesepakatan, menentukan urutan prioritas dan memberikan status relaif.

3. Kesinambungan: Mengekspresikan budaya dominant dan mengakui keberadaan kebudayaan khusus (subculture) serta perkembangan budaya baru, meningkatkan dan melestarikan nilai-nilai.

4. Hiburan: Menyediakan hiburan, pengalihan perhatian dan sarana relaksasi, meredakan ketegangan sosial.

5. Mobilisasi: Mengkampenyakan tujuan masyarakat dalam bidang politik, pembangunan, ekonomi, pekerjaan dan agama.

Selain memiliki fungsi yang demikian itu, media massa dalam kehidupan sosial, terutama dalam masyarakat modern (era globalisasi) tidak ada yang menyangkal memiliki peran yang begitu penting. Menurut McQuail (2000 : 66) dalam bukunya, Mass Communication Theories, ada enam perspektif dalam hal melihat peran media: Pertama, melihat media massa

Islamic Comunication Journal Volume 02, Nomor 02, Juli-Desember 2017 
seabagai window on event and experience. Media dipandang sebagai jendela yang memungkinkan khalayak melihat apa yang sedang terjadi di luar sana. Atau media merupakan sarana belajar untuk mengetahui berbagai peristiwa.

Kedua, media juga sering dianggap sebagai a mirror of event in society and the world, implying a faithful reflection. Cermin berbagai peristiwa yang ada di masyarakat dan dunia, yang merefleksikan apa adanya. Karenanya para pengelola media sering merasa tidak "bersalah" jika isi media penuh dengan kekerasan, konflik, pornografi dan berbagai keburukan lain, karena memang menurut mereka faktanya demikian, media hanya sebagai refleksi fakta, terlepas dari suka atau tidak suka. Padahal sesungguhnya, angle, arah dan framing dari isi yang dianggap sebagai cermin realitas tersebut diputuskan oleh para profesional media, dan khalayak tidak sepenuhnya bebas untuk mengetahui apa yang mereka inginkan.

Ketiga, memandang media sebagai filter, atau gatekeeper yang menyeleksi berbagai hal untuk diberi perhatian atau tidak. Media senantiasa memilih isu, informasi atau bentuk content yang lain berdasar standar para pengelolanya. Di sini khalayak "dipilihkan" oleh media tentang apa-apa yang layak diketahui dan mendapat perhatian. Keempat, media acapkali pula dipandang sebagai guide, penunjuk jalan atau interpreter, yang menerjemahkan dan menunjukkan arah atas berbagai ketidakpastian, atau alternatif yang beragam. Kelima, melihat media sebagai forum untuk mempresentasikan berbagai informasi dan ide-ide kepada khalayak, sehingga memungkin terjadinya tanggapan dan umpan balik.

Keenam, media sebagai interlocutor, yang tidak hanya sekadar tempat berlalulalangnya informasi, tetapi juga partner komunikasi yang memungkinkan terjadinya komunikasi interaktif. Pendeknya, semua itu ingin menunjukkkan, peran media dalam kehidupan sosial bukan sekedar sarana diversion, pelepas ketegangan atau hiburan, tetapi isi dan informasi yang disajikan, mempunyai peran yang signifikan dalam proses sosial. Isi media merupakan konsumsi otak bagi khalayaknya, sehingga apa yang ada di media akan mempengaruhi realitas subjektif pelaku interaksi sosial. Gambaran tentang realitas yang dibentuk oleh isi media inilah yang nantinya mendasari respon dan sikap khalayak terhadap berbagai objek sosial. Informasi yang salah dari media akan memunculkan gambaran yang salah pula terhadap objek sosial itu. Karenanya media dituntut menyampaikan informasi secara akurat dan berkualitas. Kualitas informasi 
inilah yang merupakan tuntutan etis dan moral penyajian media.

\section{MEDIA ISLAM DAN MEDIA ISLAMI}

Begitu luar biasanya peran media massa, sehingga dimanfaatkan oleh sebagian orang (yang tahu dan sadar) untuk menyebarkan paham atau ideologi yang dianutnya. Sebut saja Barat yang mengkampanyekan demokrasi dalam konteks politik dan kapitalisme dalam pihak ekonomi. Maka tidak heran, jika paham atau ideologi Barat sangat cepat menyebar ke seluruh dunia. Jika paham-paham itu berdampak baik, tentu tidak menjadi persoalan. Akan tetapi, jika ideologi yang menyebar itu justru berdampak negatif pada bangsa yang lain, termasuk Indonesia, tentu sangat disayangkan dan harus segera dicari solusinya.

Indonesia saat ini, disadari atau tidak, telah terpengaruh paham-paham Barat, seperti konsumerisme, hedonisme, materialisme, sampai pada perilaku westernisasi. Indonesia yang mayoritas penduduknya beragama Islam, tentu harus memiliki tolak ukur yang jelas terhadap paham-paham yang masuk itu. Tolak ukur itu, bagi umat Islam, tidak lain adalah alQur'an dan al-Hadits. Derasnya arus globalisasi yang "menyatukan" budayabudaya di dunia pada masing-masing bangsa membuat umat Islam harus juga bergerak. Berdiam diri tanpa melakukan upaya merespon globalisasi sama dengan membiarkan Islam digerus oleh agama atau paham-paham lain. Sebagai penganut agama dakwah, umat Islam harus mereformulasikan gerakan dakwah supaya tetap relevan dan bisa menyentuh seluruh elemen masyarakat di dunia, apalagi di era global sekarang ini. Karena itu, diperlukan media yang menyebarkan nilai-nilai Islam yang bersumber dari al-Qur'an dan al-Hadits.

Dalam konstelasi media yang begitu luas sekarang, ada segmen atau kategori yang dinamakan sebagai "media Islam," atau ada juga yang menyebut "media Islami." Sayangnya, kajian akademis tentang "media Islam" dan/atau "media Islami" ini belum cukup meluas. Tulisan ini berupaya memberikan kategorisasi yang lebih jelas tentang apa itu "media Islam" dan atau "media Islami," serta perbedaannya dengan media lain. Sebelumnya, perlu kejelasan apakah ada perbedaan antara media Islam dan media Islami. Bagi sebagian kalangan, dua sebutan itu mungkin berarti sama saja, alias tidak ada beda antara media Islam dan media Islami. Tetapi penulis akan mencoba membedakan makna antarkeduanya, untuk memperjelas kategorisasi bagi pengkajian lebih lanjut.

Dimulai dengan media Islam dulu. Kata "Islam" menunjukkan suatu identitas, untuk membedakan satu dengan yang lain 
(Arismunandar, 2010). Orang Islam jelas tidak sama dengan orang Kristen, Hindu, Buddha, danseterusnya. Agar bisa disebut sebagai orang Islam, orang itu minimal harus sudah mengucapkan kalimat syahadat, mengakui bahwa tiada Tuhan selain Allah, dan bahwa Nabi Muhammad SAW adalah utusan Allah. Dengan analogi semacam itu, media yang menyandang nama "media Islam" tentunya juga harus memiliki ciri atau syarat tertentu, yang membedakannya dengan berbagai media lain. Syarat pertama, untuk bisa disebut sebagai "media Islam", media itu harusdimiliki oleh orang Islam. Atau, jika kepemilikannya bersifat kolektif (misalnya, saham perusahaan media bersangkutan sudah diperjualbelikan untuk umum di bursa efek), mayoritas saham harus dimiliki oleh orang Islam. Syarat ini sangat logis. Tentunya sangat absurd, jika media yang dimiliki orang beragama Yahudi disebut sebagai media Islam.

Kedua, media itu sedikit banyak harus mengemban misi dakwah, yakni misi mengagungkan agama Allah, menyebarkan nilai-nilai ajaran Islam, memajukan dan mencerdaskan umat Islam, dan sebagainya. Adanya misi dakwah ini bukan berarti media itu harus semata-mata diisi dengankumpulan kotbah agama atau kutipan ayat kitab suci Al-Quran dan hadist Nabi. Perwujudan misi "dakwah" bisa sangat luas. Misi mencerdaskan dan memajukan umatIslam, misalnya, bisa dilakukan dengan berbagai format media. Di sini, sudah masuk unsur kreativitas pengelola media dalam mengemas misi dakwahnya. Jadi, media Islam bebas menyajikan dan mengupas topik apa saja. Mulai dari topik yang spesifik berkaitan dengan agama, sampai topik yang terkait dengan ilmu pengetahuan, teknologi, sastra, seni-budaya, sosial-ekonomi, politik, hankam, dan lain-lain. Semua itu bisa dijadikan topik, asalkan semua itu dilandasi dengan niat dakwah.Jadi, misi media Islam bukan semata-mata komersial, bukan cuma mengejar profitsebanyak-banyaknya.

Ketiga, media Islam harus menerapkan aturan, etika, dan nilai-nilai ajaran Islam, dalam menjalankan bisnis perusahaan media dan aktivitas keredaksian (editorial). Islam tidak mengenal prinsip-tujuan menghalalkan cara. Jika syarat kedua tadi berkaitan dengan niat (misi) dan tujuan ketika mendirikan media, maka syaratketiga ini berkaitan dengan cara mencapai tujuan tersebut. Etika dan nilai-nilai Islam yang harus diterapkan di sini mencakup dua aspek:aspek bisnis dalam menjalankan usaha media, dan aspek yang berkaitan dengan sisi keredaksian (editorial). Dalam aspek bisnis, misalnya, media Islam tidak membabi buta dalam mencarikeuntungan. Contohnya, tidak semua iklan, betapapun besar nilainya, akan 
diterima. Harus ada kriteria, iklan mana yang boleh atau tidak-boleh dimuat di media Islam. Media Islam akan menolak mengiklankan semua hal yang secara jelas dan tegasdiharamkan oleh Islam. Jadi, tidak akan ada iklan minuman keras atau makanan yang mengandungdaging babi di media Islam.

Soal iklan rokok, ada yang tegas mengharamkan, ada jugayang menganggapnya makruh. Namun, apapun yang dipilih, iklan rokok juga bukansesuatu yang dianjurkan karena dampak negatifnya pada kesehatan. Media Islam juga harus menerapkan peraturan ketenagakerjaan yang adil danmanusiawi buat para buruhnya. Jangan sampai tenaga buruh diperas seenaknya dan diupah di bawah standar upah minimum yang layak. Sistem kerjanya juga harusmemberi kesempatan karyawan untuk melaksanakan ibadah sholat, dan lain-lain.

Kebebasan pers adalah prasyarat bagi terwujudnya fungsi media untuk memberi informasi,mendidik masyarakat, menghibur, dan melakukan kritik sosial. Fungsi yang terakhir ini mencakup peran sebagai watchdog (anjing pengawas) terhadap penguasa. Jika tidak ada kebebasan pers, tentu pers hanya akan jadi alat penguasa. Tanpa kebebasan, media tidak bisa berperan dalam sistem demokrasi, dimana media sering disebut sebagai pilar keempar sesudah eksekutif, legislatif, danyudikatif. Namun, kebebasan pers itu juga bisa menjurus ke wujud yang ekstrem.

Dalam penerapan "kebebasan pers yang universal" itu, misalnya, tiap warga negara dianggap bebas menerbitkan media apa saja, termasuk media yang mengeksploitasi seks,kekerasan, dan sebagainya sebagai bahan jualannya. Penerbitan semacam Playboy dan Popular, yang mengumbar aurat dianggap sah-sah saja. Toh memang ada segmen pembaca tertentu yang menggemari dan selalu mengonsumsinya.Contoh lain, sejumlah media di Eropa Barat beberapa waktu lalu pernah memuat karikatur Nabi Muhammad SAW dalam format yang melecehkan. Hal ini mereka lakukan di bawah payung "kebebasan pers" dan "kebebasan berekspresi," yang dianggap sebagai bagian dari hak-hak asasi manusia. Terjadi kehebohan besar dan aksi protes massa di berbagai negara yang mayoritas penduduknya Muslim, akibat pemuatan karikatur kontroversial ini.

Nah, dalam hal-hal semacam inilah terdapat perbedaan antara media Islam dan media lain. Bagi media Islam, pengertian "kebebasan pers" dan "kebebasan berekspresi" bukanlah kebebasan yang liar semau-maunya, bukan kebebasan demikebebasan itu sendiri. Melainkan, kebebasan yang luas dalam berkreasi melalui 
media,sebagai sarana dakwah dan wujud pengabdian kepada Allah SWT.Pelayanan kepentingan publik, yang sudah jadi kredo jurnalisme universal,adalah bagian dari pengabdian kepada Allah SWT. Jadi, tidak ada ceritanya media Islam memuat konten yang cabul, yang mempromosikan gaya hidup homo seksualitas, yang melecehkan Nabi Muhammad SAW atau keluarganya, dan lain-lain, yang justru menjauhkan pembacanya dari ajaran Allah SWT.

Cukup jelas tentang media Islam, kini kita membahas media Islami. Kalau kata "Islam" menunjukkan identitas, maka kata "Islami" menunjukkan suatu sifat atau ciri yang merujuk ke identitas "Islam." Orang Islam yang sepenuhnya patuh, tunduk pada Allah dan Rasul-Nya, dan mengimplementasikan ajaran Islam pada seluruh aspek kehidupannya, akan menunjukkan ciri-ciri Islami. Yaitu, ciri-ciri itu terlihat mulai daricaranya bergaul dengan tetangga, cara berkata-kata, cara memimpin, sampai caramemperlakukan suami/istri. Namun, ciri Islami ini mungkin tidak terwujud dalam seluruh aspek kehidupan.Misalnya, kita mungkin pernah bertemu orang yang pantang minum bir atau minuman beralkohol lain. Ia juga pantang makan daging babi, anjing, dan semua makanan yang jelas dan tegas diharamkan dalam Islam. Orang itu bahkan rajin berpuasa Senin-Kamis.Tetapi orang itu ternyata sangat kikir, tidak pernah mau berzakat atau berinfaq padafakir miskin. Jadi, perilakunya terhadap makanan terkesan "Islami," tetapi perilaku kikirnya jelas "tidak Islami."

Orang Islam yang sepenuhnya melaksanakan ajaran Islam, pastilah akan menunjukkan ciri-ciri Islami dalam seluruh cara hidupnya. Sebaliknya, orang yang menunjukkan ciri Islami tidak otomatis berarti orang itu adalah orang Islam. Karena, bisa jadi "ciri Islami" itu tidak berangkat dari ajaran Islam sebagai landasannya. Ciri-ciri itu lebih terlihat pada tampilan, pada permukaan, tetapi tampilan tidak selalu mencerminkan esensi. Dalam kasus orang yang pantang makan daging babi dan menenggak minuman beralkohol, misalnya, bisa jadi dia melakukan itu karena alasan kesehatan semata-mata (daging babi mengandung banyak lemak, sedangkan minuman beralkohol merusak ginjal). Jadi, niatnya sekadar mengikuti instruksi dokter, bukan karena untuk mematuhi ajaran Islam. Banyak orang non-Muslim bahkan berpantang daging sama sekali, menjadi vegetarian, karena pertimbangan kesehatan.

Dengan analogi tersebut, dapat dikatakan bahwa media Islam itu identik atau seharusnya identik dengan media Islami. Tetapi, sebaliknya, media "Islami" belum 
tentu bisa dikategorikan sebagai media Islam, karena boleh jadi ciri "Islami" itu hanya pada salah satu atau sebagian aspek saja. Kalau seluruh aspeknya sudah "Islami," maka barulah ia bisa disamakan dengan media Islam. Misalnya, ada sebuah media yang menolak memasang iklan minuman keras, makanan yang mengandung daging babi, dan hal-hal lain yang diharamkan dalam Islam. Dalam pemberitaannya juga menolak mempromosikan hal-hal yang terlarang dalam Islam (pornografi, seks bebas, gaya hidup homoseksual, dan sebagainya). Bisa dibilang, bahwa dalam aspek kebijakan pemasangan iklan dan aspek kebijakan redaksional, media itu "Islami." Tetapi media "Islami" itu bukan media Islam, karena tidak dimiliki oleh orang Islam.

Demikianlah sekadar sumbangan saya, dalam upaya memberi kategorisasi yang lebih jelas, untuk membedakan antara media Islam, media Islami, dan media lainnya. Semoga kategorisasi ini bisa bermanfaat bagi pengkajian akademis lebih lanjut tentang media Islam.

\section{PROSPEK DAKWAH MEDIA MASSA DI ERA GLOBAL}

Media massa merupakan sarana penyebarluasan berita dan informasi kepada khalayak luas, baik secara local, nasional, maupun internasional. Hal ini selaras dengan fungsi media massa sebagai lembaga siaran yang berkepentingan dengan penyebaran informasi dan bisnis serta upaya mempengaruhi opini public internasional (Shoelhi : 2009).

Professor David Hill (2001) dalam Pers Indonesia dalam Konteks Asia: Gambaran Sepintas Lalu mengatakan maraknya kemunculan media-media baru di Indonesia sebenarnya bisa menjadi hal yang menguntungkan. Tetapi, menurutnya, yang harus diwaspadai adalah soal kepemilikan media. "Jangan sampai Indonesia meniru Australia, di mana hanya satu, dua orang saja atau sejumlah orang yang sangat kecil jumlahnya yang menguasai melalui kepemilikannya," Selama ini di Australia, menurutnya, sudah ada praktik tidak tertulis di mana mereka yang mengontrol media tidak melibatkan diri secara langsung, walaupun media masih memberikan warna di dalam gambaran keseluruhan suasana politik Australia. Di Australia, pemilik perusahaan media tahu diri untuk tidak ikut terjun langsung dalam kancah politik. Meski demikian, tetap saja ada praktik-praktik dimana beberapa media mendukung beberapa partai politik tertentu. Terutama saat pemilihan umum, beberapa kandidat mendekati media-media.

Untuk melihat sejauh mana masyarakat Indonesia membaca media massa online, atau media mana yang paling banyak dibaca,

Islamic Comunication Journal Volume 02, Nomor 02, Juli-Desember 2017 
dapat dilihat pada situs www.alexa.com. Berdasarkan catatan alexa.com, tidak ada satupun media yang dikategorisasikan sebagai media Islam yang berada pada posisi 500 besar. Hanya ada satu media yang disinyalir sebagai media Islami yang berada pada peringkat 53, yaitu repubika.co.id. Pada urutan 10 besar, terdapat beberapa media mainstream yang selama ini menjadi rujukan pemberitaan nasional, semisal Tribunnews,com, Detik.com, Kompas.com, Liputan6.com, Merdeka.com, Okezone.com, dan Tempo.co.

Berikut peringkat 25 besar situs yang masuk kategori "Top Sites in Indonesia" menurut situs alexa.com:

\begin{tabular}{|l|l|l|}
\hline \multicolumn{3}{|c|}{ Alexa.com } \\
\hline 1) Google.com & 9) Kompas.com & 17) Okezone.com \\
2) Google.co.id & 10) Bukalapak.com & 18) Bola.net \\
3) Youtube.com & 11) Kaskus.co.id & 19) Instagram.com \\
4) Facebook.com & 12) Liputan6.com & 20) Lazada.co.id \\
5) Tribunnews.com & 13) Kapanlagi.com & 21) Elevenia.co.id \\
6) Detik.com & 14) Bogger.com & 22) Wikipedia.ord \\
7) Yahoo.com & 15) Worddpress.com & 23) Tempo.co \\
8) Tokopedia.com & 16) Merdeka.com & 24) Onclickads.net \\
& & 25) Blogspot.com \\
\hline
\end{tabular}

Berdasarkan pengamatan terhadap rating situs media Islam di Indonesia tersebut, perlu dipikirkan ulang model media "Islam" yang seerti apa yang efektif dapat membantu menyebarkan nilai-nilai Islam. Jika melihat rating, media yang lebih bisa diharapkan adalah media Islami, yang di atas bisa dilihat pada situs republika.co.id. Media semacam republika ini sebaiknya yang diperbanyak. Selain itu, representasi media Islam sulit dikendalikan. Dengan kata lain, karena pemahaman Islam yang berbeda-beda masing-masing muslim, $210 \mid \begin{aligned} & \text { Islamic Comunication journal } \\ & \text { Volume 02, Nomor 02, Juli-Desember } 2017\end{aligned}$ mengakibatkan keberagaman yang di sisi lain justru merugikan Islam. Contoh yang mudah dilacak adalah pemblokiran situs radikal oleh Kementerian Komunikasi dan Informasi (Kemkominfo) pada dua tahun terakhir ini. Ada 22 situs internet radikal yang diadukan oleh Badan Nasional Penanggulangan Terorisme (BNPT), kata Ismail, di Jakarta, Senin (30/3). Menurutnya, awalnya pihaknya telah memblokir 3 (tiga) situs, namun BNPT melaporkan kembali untuk memblokir 19 situs berdasarkan surat bernomor No 
149/K.BNPT/3/2015 tentang Situs/Website Kemkominfo.

Radikal ke dalam sistem filtering

Untuk itu, Kemkominfo meminta penyelenggara internet service provider (ISP) untuk memblokir ke-19 situs sesuai yang disampaikan pihak BNPB bahwa situs/website tersebut merupakan situs/wensite penggerak paham radikalisme dan/atau simpatisan radikalisme. Adapun ke-22 situs yang telah diblokir (Kominfo.go.id, 30 Maret 2015) yakni:

\begin{tabular}{|l|l|l|}
\hline 1) arrahmah.com & 8) an-najah.net & 15) muqawamah.com \\
2) voa-islam.com & 9) muslimdaily.net & 16) lasdipo.com \\
3) ghur4ba.blogspot.com & 10) hidayatullah.com & 17) gemaislam.com \\
4) panjimas.com & 11) salam-online.com & 18) eramuslim.com \\
5) thoriquna.com & 12) aqlislamiccenter.com & 19) daulahislam.com \\
6) dakwatuna.com & 13) kiblat.net & 20) shoutussalam.com \\
7) kafilahmujahid.com & 14) dakwahmedia.com & 21) azzammedia.com \\
\hline 22) &
\end{tabular}

Pada awal 2016 lalu, Kemenkominfo juga telah memblokir 24 situs tambahan. Ke-24 situs yang diblokir pemerintah yaitu (Kompas, 26 Januari 2016):

1. https://abdulloh7.wordpress.com/

2. http://ruju-ilalhaq.blogspot.co.id/

3. http://fursansyahadah.blogspot.co.id/

4.

https://karawangbertawhid.wordpress. com/

5. http://terapkan-tauhid.blogspot.co.id/

6. https://arrhaziemedia.wordpress.com/

7. http://syamtodaynews.xyz/

8.

https://anshardaulahislamiyahnusantar a.wordpress.com/

9. http://jihadsabilunadakwah.blogspot.co.id/

10. http://kupastajam.blogspot.co.id/
11. https://mabesdim.wordpress.com/

12. http://anshorullah.com/

13. http://ajirulfirdaus.tumblr.com/ 14.

http://batalyontauhidwassunnahwaljih ad.blogspot.co.id/

15.

http://anshoruttauhidwassunnahwaljih ad.blogspot.co.id/

16. https://jalanallah.wordpress.com/

17. https://religionofallah.wordpress.com/ 18. http://daulahislamiyyah.is-great.org/ 19. http://ummatanwahidatan.is-great.org/ 20. http://metromininews.blogspot.co.id/ 21. http://al-khattab1.blogspot.co.id/ Islamic Comunication Journal Volume 02, Nomor 02, Juli-Desember 2017 
22. http://fadliistiqomah.blogspot.co.id/

23. https://daulah4islam.wordpress.com/

24. www.muharridh.com

Tentu saja ini menjadi cambuk bagi umat Islam. Situs-situs yang seharusny menjadi media dakwah justru berlaku sebaliknya dengan mencoreng nama Islam itu sendiri. Hal ini tidak terlepas dari kepentingan sekelompok orang yang mengatasnamakan Islam atau orang Islam yang mengikuti paham Islam radikal.

Selain situs radikal, Kemenkominfo mengaku telah menerima banyak laporan terkait akun media sosial dengan berbagai konten yang mengandung pornografi anak. Akun tersebut dikatakan sedang dalam proses untuk diblokir. Jika kita berbicara tentang jejaring sosial yang semakin menguat: Indonesia adalah salah satu pengguna Facebook terbanyak di dunia. Menurut laporan majalah Forbes, meski kini telah dikalahkan oleh India, jumlah pengguna Facebook di Indonesia masih menduduki salah satu posisi teratas di dunia bersama dengan Brasil, India, Meksiko, Inggris Raya, dan negara asal Facebook, dibuat oleh orang muslim dan berisikan konten dan cara yang Islami. Beberapa contoh diantaranya adalah Facelim.com, Nahnumuslim.com, Pencerahan Hati.com, Salingsapa.com, dan lain-lain.
Amerika Serikat, yang masih memiliki pengguna Facebook terbanyak.

Budiono Darsono, salah satu pendiri portal berita Detik.com, dalam review buku Detik.com: Legenda Media Online (2013) mengatakan dengan melihat jumlah pengguna jejaring sosial yang terus bertambah, maka tidak ada pilihan lain bagi media untuk memanfaatkannya sebagai bagian dari praktik jurnalisme. Jejaring sosial, seperti Facebook dan Twitter, bukan sekedar memberikan masukan atau kritik, tetapi juga malah memberikan informasi (Anggoro, 2013). Selain itu, banyaknya masyarakat yang aktif di jejaring sosial menyebabkan banyak waktu yang terbuang dengan sia, jika tidak digunakan dalam konteks yang positif. Aktivis dakwah harus melihat hal ini sebagai tantangan sekaligus peluang untuk mendulang jamaah dengan model dakwah yang lebih canggih, memanfaatkan teknologi. Karena itu, umat Islam juga perlu mengerti teknologi, bahkan harus ada yang ahli dalam bidang ini. Sebetulnya, ada beberap media sosial yang

\section{ULAMA DAN TANTANGAN DAKWAH ERA MEDIA SOSIAL}

Islam merupakan agama dakwah baik secara teoritis maupun praktis sebagai agama dakwah, kedudukan Islam melebihi agama-agama dakwah yang lain dan ini

$212 \mid \begin{aligned} & \text { Islamic Comunication journal } \\ & \text { Volume 02, Nomor 02, Juli-Desember } 2017\end{aligned}$ 
disebabkan oleh klaim Islam sendiri bahwa ia merupakan wahyu terakhir dan penyempurna dari agama-agama sebelumnya terutama Yahudi dan Nasrani. Ismail Raji Al Faruqi, dengan mengutip beberapa ayat al-Qur'an menegaskan bahwa dakwah bukan saja merupakan keharusan melainkan tugas terbesar kaum muslim yang harus ditunaikan, karena itu, dapat dipahami jika semangat untuk menyampaikan dan memperjuangkan kebenaran Islam terus membara dalam jiwa muslim. Bahkan, Ismail Raji al-Faruqi (1989: 187-188) menjelaskan, cita-cita hidup seorang muslim yang taat adalah membawa manusia ke dalam suatu kehidupan yang Islam dapat diterima dan menjadi agama (system hidup seluruh umat di dunia). Dakwah adalah cara untuk merealisasikannya.

Dakwah menurut Syaikh Ali Mahfudz dalam kitabnya, Hidayatul Mursyidin (tt: 17) adalah mendorong manusia agar berbuat kebaikan dan mengikuti petunjuk (alhidayah), menyeru mereka berbuat kebaikan dan mencegah dari kemungkaran, agar mereka mendapat kebahagiaan di dunia dan akhirat. Sedangkan Muhammad Abu al-Fath al-Bayanuni (1993: 17) memberikan ta'rif bahwa dakwah adalah menyampaikan dan mengajarkan agama Islam kepada seluruh manusia dan mempraktekkannya dalam kehidupan nyata. Agar Islam dapat terus menyebar dan meresapi jiwa dan raga para pengikutnya, maka dakwah harus terus dikembangkan sesuai dengan perkembangan zaman.

Berkaitkan dengan kompleksitas perubahan era informasi dan pasca-industri, banyak masalah yang harus dihadapi dan diselesaikan oleh dakwah jika tidak ingin eksistensinya tenggelam dalam perubahanperubahan yang sedang dan akan berlangsung. M. Nafis (2005: 10-11) menyatakan bahwa perlu adanya pencarian format dan konstruk dakwah yang efektif dan operasional baik pada struktur, materi, pendekatan dan metodenya. Sedangkan konstruk dakwah sangat dipengaruhi oleh kualitas interaksi antara pembakuan ideologi dasar dengan kreatifitas para pendukung dakwah dalam menampilkan ideologi tersebut sesuai dengan struktur dan pola kultur yang berkembang. Oleh sebab itu, konstruk dakwah harus mendasarkan diri pada asas konsistensi, kreatifitas dan fleksibelitas yang tinggi. Dakwah harus dipahami bukan hanya dengan ceramah atau pidato-pidato saja, tetapi dakwah merupakan segala aktivitas, baik dalam bidang keagamaan, ekonomi, sosial, pilitik, maupun kebudayaan yang tujuannya adalah untuk kebahagiaan dunia dan akhirat (Aziz, 
2016: 262). Media massa adalah salah satu yang perlu dioptimalkan.

Pada level arus globalisasi yang dicirikan penggunaan media elektronik, komputer dan media cetak, redefinisi dakwah pada bidang-bidang tersebut perlu dilakukan. Seperti yang telah diuraikan sebelumnya bahwa difusi dan infiltrasi kebudayaan merupakan fenomena umum dalam era globalisasi. Oleh sebab itu bukan tidak mungkin bahwa dakwah dengan muatan-muatan doktrinal-empiriknya akan terlibat dalam proses difusi dan infiltrasi kebudayaan tersebut. Hanya saja kemampuan dan kecakapan untuk memanfaatkan berbagai media dan sarana tersebut perlu ditangani secara serius dengan mengintensifkan pelatihan dan pengadaan prasarananya (jika dipandang mungkin). Meskipun tidak harus berarti bahwa media tradisional diterlantarkan (Nafis, 2005: 9).

Terdapat kesimpulan yang cukup kuat bahwa mekanisme dakwah masih tertatihtatih dan belum mampu mengimbangi tuntutan-tuntutan dasar era informasipasca industri-perubahan yang ada. Kesenjangan antara konstruk dakwah dengan realitas sosial demikian lebar j Solusi sering bersifat parsial, itupun tidak didasarkan pada analisis masalah aktual yang berkembang. Organisasi dakwah telah berkembang, tetapi masih bergerak terserak dan sedikit yang ditata dengan manajemen modern (Nafis, 2005: 7).. Akibatnya media elektronik dan cetak tidak secara efektif digunakan untuk aplikasi dakwah dan pada akhirnya problematika yang berkembang terbengkalai dan tidak mendapatkan jawaban yang berarti.

Dengan tingkat kemajuan ilmu pengetahuan dan teknologi yang selalu mengasumsikan dinamika yang tak terbatas, maka tingkat manipulasi terhadap alam juga akan semakin luas dan mencapai kawasankawasan yang semula tak terbayangkan. Teknologi informasi dan jasa, yang oleh sebagian kalangan dikategorikan sebagai manifestasi budaya pasca modern (Johnson, 1986: 23), telah menghantarkan proses globalisasi semakin cepat dan sekaligus ketergantungan yang semakin akut.

Dengan kecanggihan teknologinya, media massa saat ini lebih memudahkan proses penyebaran dakwah. Paul Lazarsfeld dan Robert K Merton (2008: 38) juga melihat media dapat menghaluskan paksaan sehingga tampak sebagai bujukan. Sejalan dengan itu harus dipahami manfaat dan mudharat teknologi informasi dan komunikasi, serta secara sadar memanfaatkannya untuk mencapai tujuan kita, bukan tujuan-tujuan mereka (pembuat dan pencipta teknologi). Dengan kata lain, sebagai pengguna informasi baik sebagai

$$
214 \mid \begin{aligned}
& \text { Islamic Comunication journal } \\
& \text { Volume 02, Nomor 02, Juli-Desember } 2017
\end{aligned}
$$


subjek atau pun objek jangan sampai terjebak dengan kepentingan-kepentingan yang tersembunyi di balik kecanggihan media tersebut.

Dengan demikian tantangan para dai untuk berdakwah semakin tinggi, di saat akses terhadap pemanfaatan teknologi informasi dan komunikasi semakin terbuka akan tetapi di lain pihak profesionalisme lembaga dakwah dan para dai dituntut lebih baik, serta tantangan yang paling berat adalah dikala memanfaatkan media yang yang sudah menjadi industri yang profitable untuk tujuan dakwah, dibalik pesan-pesan yang disampaikan. Sebab pemanfaatan teknologi informasi dan komunikasi dewasa ini adalah suatu keniscayaan yang tidak mungkin diabaikan.

Seperti media internet yang akhirakhir ini perkembangannya sangat fenomenal memiliki pengaruh langsung yang sangat kuat kepada pembacanya. Internet mampu menggerakkan prilaku massa sesuai dengan arah yang dikehendakinya. Kenyataanya massa tidak memiliki daya apa-apa, sehingga karena kehalustajamannya itu, Jalaluddian Rakhmat melukiskannya ibarat seorang pasien yang tidak berdaya apa-apa setelah dimasuki sejenis serum melalui jarum kecil dalam tubuh (Rakhmat, 1988, 88). Jaringan sosial di dunia maya tersebut sangat potensial untuk dimanfaatkan sebagai sarana dakwah.

Ulama harus tetap menjalankan fungsinya sebagai pewaris para nabi dengan melakukan dakwah yang tantangannya sangat kompleks. Media sosial menjadi salah satu alternatif media (wasilah) dakwah yang bisa dimaksimalkan, mengingat masyarakat Indonesia kini hampir-hampir $50 \%$ menggunakan internet, terutama media sosial. Tentu ini menjadi ladang basah yang harus digarap oleh mereka, sekalipun dalam ladang itu banyak terdapa ular dan lintah yang senantiasa mengancam. Karena itu, diperlukan kesiapan lahir batin untuk menjalaninya.

Pada akhir 2016, empat orang dari berbagai daerah datang ke kediaman pengasuh Ponpes Raudlatut Thalibin, Ahmad Mustofa Bisri (akrab disapa Gus Mus) di Rembang, Jawa Tengah. Mereka minta maaf telah menghina di media sosial. Selain Gus Mus, Rais Syuriah PBNU KH Ma'ruf Amin telah memaafkan Boni Hargens yang telah mengunggah ulang foto pernikahan tahun 2014 lalu. Sebelumnya, Boni telah meminta maaf atas tindakannya tersebut. Dia mengaku salah: seharusnya 
menyimpan gambar, namun malah mempostingnya di Twitter.(Detik.com)

Berkaitan dengan itu, Ahmad Mustofa Bisri menyebut para pemuda yang telah berkata-kata kasar kepadanya di medsos ini hanyalah salah pergaulan. Dia pun menyoroti bagaimana 'sakti'-nya medsos bisa mengubah orang-orang yang santun di dunia nyata menjadi buruk perilakunya di dunia maya. Oleh karena itu, Gus Mus mengemukakan beberapa hal yang perlu diperhatikan para netizen:

Kepada mereka ini dan semisal mereka bukan yang sengaja menjadikan sosmed sebagai sarana menebar kebencian dan kekacauan kalau boleh, aku menasihatkan agar: (1) menata kembali niat kita dalam menggunakan dan memanfaatkan Sosmed; (2) berhati-hati dan waspada beraktivitas di 'dunia maya' yang penuh tipuan; (2) jangan mudah tergiur dengan tampilantampilan menarik, biasakan tabayun dan meniliti rekam-jejak; (3) jangan tergesagesa membaca dan membagikan bacaan; (4) usahakan sekali-kali KopDar, agar bisa melihat Manusia dalam penampilan nyatanya (dalam hal ini, contohlah misalnya perkawanan maya dan nyata dari misalnya komunitas Adib Machrus, Pakdhe Tegoeh, Timur Suprabana, Zen Mehbob, Triwibowo Budi Santoso, Zaenal Maarif, dan mereka yang tidak hanya bersapaan di sosmed tapi juga bersilaturahmi di dunia nyata. Mereka guyub, penuh kasih sayang); (5) ingat sabda Rasulullah SAW "Innamal a'mãlu binniyãt... alhadits" dan "Min husni Islamil mar-i tarkuhu mã lã ya'ni'.(Mustafa Bisri, Facebook.com)

Fakta di atas menunjukkan bahwa media sosial ibarat bara yang bisa digunakan untuk memasak sate, ikan, ayam, bebek, dll, akan tetapi juga bisa membakar segalanya. Oleh sebab itu, jika ulama terjun di media sosial, jangan sampai terjebak dalam fragmen-fragmen tertentu dan harus menjadi problem solver umat yang bermain media sosial. Proses ini merupakan dinamisasi dakwah dalam menjamu pergerakan zaman, sama halnya dengan dakwah memanfaatkan media radio dan televisi sewaktu awal keberadaanya. Social media di dunia maya sangat potensial untuk dimanfaatkan sebagai sarana dakwah. Tentu saja, para ulama tidak boleh melupakan dan mengabaikan tenaga-tenaga yang akan mengisi aktivitas dakwah di masjid-masjid, pondok pesantren, majelis taklim, dan sejenisnya yang selama ini sudah berjalan. 


\section{PENUTUP}

Sebagai bagian penting kehidupan masyarakat modern, media massa memiliki peranan yang vital terhadap ideologi dan akhlak suatu bangsa. Dengan kata lain, baik tidaknya akhlak suatu bangsa salah satunya sangat ditentukan oleh media. Karena itu, media harus diisi oleh konten-konten terbaik untuk pencerahan dan perbaikan generasi masa depan. Dalam konteks agama, umat Islam harus hadir untuk menyampaikan pesan-pesan dakwahnya sebagai bagian penting imlementasi nilai-nilai Pancasila. Kehadiran umat Islam bisa berwujud pada media Islam dan islami. Keduanya memiliki peluang yang sama-sama khas untuk bersaing menyebarkan pesan moral dan esensi agama yang diperlukan bangsa Indonesia.

Rekomendasi dari penulis bhwa penelitian yang dalam terkait efektivitas media Islam dan media Islami perlu dilakukan ke depan, supaya bisa menjadi bahan evaluasi para praktisi media, terutama yang muslim sekaligus juga bagi para aktivis dakwah agar lebih cerdas memanfaatkan media massa sebagai bagian penting dari unsur dakwah yng sangat menentukan. Terakhir, penulis menyampaikan permohonan maaf atas kesalahan dalam penulisan artikel ini sekaligus meminta saran dan masukan untuk hasil yang lebih baik

\section{DAFTAR PUSTAKA}

Achmad, Amrullah dkk., Dakwah Islam dan Perubahan Sosial, (Yogyakarta: PLP2M, 1983).

al-Bayanuni, Muhammad Abu al-Fath, al Madkhal ila 'Ilm al Da'wah, (Beirut: Muassaah al-Risalah, 1993).

al-Faruqi, Ismail Raji dan Lois Lamya alFaruqi, The Cultural Atlas of Islam, (New York: Macmillan Publishing Company, 1986).

Anggoro, A. Sapto, Detik.com: Legenda Media Online (Yogyakarta: Moco Media, 2013).

Arismunandar, Satrio, Media Islam, Media Islami, dan Perbeedaannya dengan Media Lain, (Depok: Makalah, 2010) http://satrioarismunandar6.blogspot.c o.id/

Aziz, Mokhamad Abdul, Korupsi dan Ancaman Demokrasi, (Semarang: Pustaka Denena, 2016).

Cangara, Hafied, Pengantar Ilmu Komunikasi, (Jakarta: PT RajaGrafindo Persada, 2002).

Fog, Agner, The Supposed and the Real role of Mass Media in Modern Democracy, (Working Paper).

Hill, D, Pers Indonesia dalam Konteks Asia: Gambaran Sepintas Lalu (Jakarta: Kompas, 2001).

Johnson, Doyle Paul, Teori Sosiologi Klasik dan Modern, I, terj. Robert

Islamic Comunication Journal Volume 02, Nomor 02, Juli-Desember 2017 
M.Z. Lawang (Jakarta:PT. Gramedia, 1986).

L. Rivers, Wiliam dan W. Jensen, Jay, Media Massa dan Masyarakat Modern, (Jakarta: Prenada Grup, 2008).

Mahfud, Syekh Ali, Hidayatul Mursyidin, (Libanon: Darul Ma'rifat, $t$ t)

Mc.Quail, Denis, Mass Communication Theories: Fourth Edition. (London: Sage Publication, 2000).

Mc.Quail, Dennis, Teori Komunikasi Massa, (Jakarta: Erlangga, 2005).

Nafis, M., "Transformasi Sosial dan Dakwah di Era Milenium III", (Teologia Volume 16, Nomor 2, Juli 2005).

Rakhmat, Jalaluddin, Psikologi Komunikasi, (Bandung: PT Remaja Rosdakarya, 1988).

Shoelhi, Muhammad, Komunikasi Internasional: Perspektif Jurnalistik. (Bandung: Simbiosa Rekatama Media, 2009).

Detik.com, "Cerita Kearifan Ulama Saat Dihina di Medsos, dari Gus Mus hingga Ma'ruf Amin", 28 November 2016,

(https://news.detik.com/berita/d3356210/cerita-kearifan-ulama-saatdihina-di-medsos-dari-gus-mushingga-maruf-amin/3), diakses 13 Januari 2017 pukul 17.30 Wib.

Mustafa Bisri, "Jum'at dan Silaturahmi", Facebook.com, 27 Novemer 2016

$218 \mid \begin{aligned} & \text { Islamic Comunication journal } \\ & \text { Volume 02, Nomor 02, Juli-Desember } 2017\end{aligned}$ (https://www.facebook.com/simbah. kakung/posts/10202832581691128), diakses 13 Januari 2017 pukul 17.35 Wib.

Alexa.com

http://www.alexa.com/topsite s/countries/ID diakses 13

Oktober 2016 pukul 17.35 Wib.

Kominfo,

https://kominfo.go.id/index.p hp/content/detail/4627/BNPT -Minta-Kominfo-Blokir-22$\underline{\text { Situs-Radikal/0/berita_satker }}$ diakses 13 Oktober 2016 pukul 17.35 Wib.

Kompas,http://tekno.kompas.com/read/20 $\underline{16 / 01 / 26 / 15345707 / \text { Kemenko }}$ $\underline{\text { minfo.Kembali.Blokir.24.Situ }}$ s.Radikal diakses 13 Oktober 2016 pukul 17.35 Wib. 